\title{
Familial Amyloid Polyneuropathy - A Family Case
}

\author{
Fan Yang1,2, Tan Juan ${ }^{1,2}$, Wang Xiao-Ming ${ }^{1,2}$ and Zhang Xiao-Dong ${ }^{2 *}$ \\ ${ }^{1}$ Department of Neurology, The Affiliated Hospital of North Sichuan Medical, \\ Sichuan, China \\ ${ }^{2}$ Institute of Neurology, North Sichuan Medical College, Sichuan, China \\ *Corresponding Author: Zhang Xiao-Dong, Institute of Neurology, North Sichuan \\ Medical College, Sichuan, China.
}

Received: October 28, 2021

Published: November 30, 2021

(C) All rights are reserved by Zhang

Xiao-Dong., et al.

\begin{abstract}
Familial Amyloid Polyneuropathy (FAP) is a relatively rare hereditary amyloidosis, which is an autosomal dominant genetic disease. It is a progressively worsening neurological disease with sensory, motor and autonomic neuropathy as the main manifestations. Patients often have obvious autonomic nervous function, heart, and eye involvement. It is rarer that the disease is manifested by pure peripheral nerve damage. This article reports a case of FAP with pure peripheral nerve damage to the family, in order to improve the neurologist's understanding of the disease.
\end{abstract}

Keywords: Familial Amyloid Polyneuropathy; Electroneuromyogram; Peripheral Neuropathy; Transthyretin Gene

\section{Case Description}

An elderly male patient, 74 years old, a farmer, was admitted to the hospital on March 02, 2021 due to "progressive numbness of the limbs for $30+$ years, aggravated limb weakness for $1+$ years". In $30+$ years, the patient had numbness in his limbs without obvious inducements, mainly located at the fingertips and toes, with intermittent symptoms. Consciously the symptoms were obvious in winter and improved on summer. 1+ years ago, the above symptoms gradually worsened, continued to be unable to be relieved, and limb weakness developed from the distal to the proximal, mainly manifested as unstable holding, unstable walking, and inability to stand up after squat. During the course of the disease, there was no water choking or difficulty in swallowing. Since the disease, the patient's spirit, diet and sleep was normal, stool and urine were normal, and there was no significant change in recent weight. He has a history of hypertension for $10+$ years, the highest blood pressure is unknown, he usually self-administered spironolactone to control his blood pressure, stopped the medication 1+ months before admission, and did not regularly monitor blood pressure; personal and family history is not special.
Physical examination

Mild edema below knee joint of both lower limbs, thinning and dull nails of both upper limbs. Neurological examination: The patient's left upper limb muscle strength is level 4, right upper limb muscle strength is level 3 , and both lower limbs muscle strength is level 4, The bilateral tendon reflexes are not elicited; the superficial sensation of the limbs is decreased, which is obvious on the left side. The rest of the physical examination showed no obvious abnormalities.

\section{Auxiliary examinations}

Standing blood pressure and supine blood pressure: normal; Cerebrospinal fluid: pressure $142 \mathrm{~cm} \mathrm{H}_{2} \mathrm{O}$, Cell count: $4 * 106 / \mathrm{L}$ (normal range 5-10*106/L), Total protein: $553.01 \mathrm{mg} / \mathrm{L}$ (normal range 150-450 mg/L), Sugar, chloride, bacterial smear and culture were normal. 24 items of peripheral ganglioside antibody were negative. Blood tests: Blood routine examination: hemoglobin 125 g/L; Connective tissue: antinuclear antibody 1:100 +; Serum lipid, liver function, renal function, electrolyte, thyroid function, cause analysis of anemia, myocardial injury markers, glycosylated hemoglobin, blood transfusion and immunization, coagulation function 
test, and anti-neutrophil plasma antibody were normal. Electroneuromyography: Peripheral nerves of the upper and lower limbs were significantly damaged, sensorimotor fibers were significantly involved, axonal damage accompanied by demyelination, but cervical and lumbar nerve roots or forefoot damage were not excluded (Figure 1). Imaging examination: MRI of cervical spine: 1 . Left and rear herniation of $\mathrm{C} 3 / \mathrm{C} 4, \mathrm{C} 4 / \mathrm{C} 5, \mathrm{C} 5 / \mathrm{C} 6$ intervertebral discs, and bulging with C5/C6 intervertebral discs; 2 . Degenerative changes of cervical spine; 3. No abnormality was found in cervical spinal cord; Head MRI+MRA, cardiac ultrasound, abdominal ultrasound and lower limb vascular ultrasound were normal.

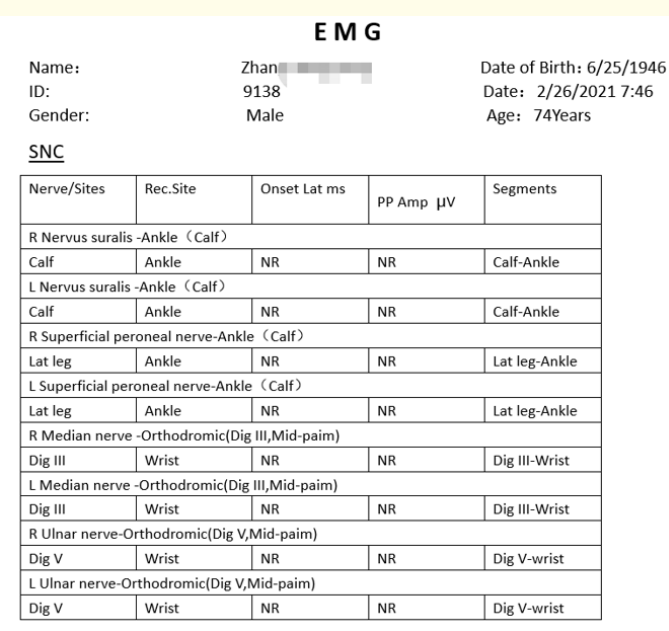

MNC

\begin{tabular}{|c|c|c|c|c|c|c|c|c|c|}
\hline $\begin{array}{l}\text { Nerve/ } \\
\text { Sites }\end{array}$ & Muscle & Segments & $\begin{array}{c}\text { Latency } \\
\text { MS }\end{array}$ & $\begin{array}{l}\mathrm{N}^{-} \\
\mathrm{Amp} \\
\mathrm{mV}\end{array}$ & $\begin{array}{r}\text { P-P } \\
\text { Amp } \\
\text { mV }\end{array}$ & $\begin{array}{c}\text { Duration } \\
\qquad \mathrm{mm}\end{array}$ & $\begin{array}{c}\text { Distance } \\
\mathrm{mm}\end{array}$ & $\begin{array}{c}\text { Velocity } \\
\mathrm{m} / \mathrm{s}\end{array}$ & $\begin{array}{l}\text { area } \\
\mathrm{mVms}\end{array}$ \\
\hline \multicolumn{10}{|c|}{$\mathrm{R}$ Median nerve - $A \mathrm{~PB}$} \\
\hline Wrist & APB & Wrist-APB & 8.02 & 0.6 & 1.2 & 6.50 & & & 2.9 \\
\hline Elbow & APB & Elbow-lirist & 14.35 & 0.8 & 1.3 & 6.52 & 205 & 32 & 3.3 \\
\hline \multicolumn{10}{|c|}{ L Median nerve - APB } \\
\hline Wrist & APB & Wrist-APB & 6.44 & 1.7 & 2.9 & 7.04 & & & 6.9 \\
\hline Elbow & APB & Elbow-Wrist & 11.54 & 1.6 & 2.8 & 6.63 & 200 & 39 & 6.5 \\
\hline \multicolumn{10}{|c|}{ R U1nar nerve -ADM } \\
\hline Wrist & ADM & \begin{tabular}{|l|l|} 
Trist- ADM \\
\end{tabular} & 3.75 & 3.9 & 6.3 & 5.50 & & & 11.5 \\
\hline B. E1bow & ADM & B. Elbow - Wrist & 7.67 & 3.6 & 6.1 & 5.79 & 185 & 47 & 11.9 \\
\hline \multicolumn{10}{|c|}{ L U1nar nerve -ADM } \\
\hline Wrist & ADM & Wrist-ADM & 3.65 & 5.6 & 7.8 & 6.71 & & & 23 \\
\hline B. E1bow & ADM & B. Elbow - rist & 7.46 & 5.7 & 8.6 & 6.94 & 195 & 51 & 23.5 \\
\hline \multicolumn{10}{|c|}{$R$ Nervus suralis-EDB } \\
\hline Ank1e & EDB & Ank1e-EDB & NR & NR & $\mathrm{NR}$ & $\mathrm{NR}$ & & & $\mathrm{NR}$ \\
\hline \multicolumn{10}{|c|}{ L Nervus suralis -EDB } \\
\hline Ankle & EDB & Ankle-EDB & 3.17 & 0.2 & 0.2 & 7.48 & & & 0.9 \\
\hline Fib head & EDB & Fib head - Ank1e & 11. 27 & 0.1 & 0.2 & 8.08 & 290 & 36 & 0.8 \\
\hline \multicolumn{10}{|c|}{ R Nervus tibialis-AH } \\
\hline Ankle & $\mathrm{AH}$ & Ankle-AH & 4.33 & \begin{tabular}{|l|l} 
\\
\end{tabular} & 0.8 & 4.54 & & & 1.5 \\
\hline $\begin{array}{l}\text { Pop } \\
\text { fossa }\end{array}$ & AH & \begin{tabular}{|lr} 
Pop & fossa- \\
Ankle & \\
\end{tabular} & 16.68 & 0.5 & 0.8 & 3. 42 & 370 & 30 & 1.0 \\
\hline \multicolumn{10}{|c|}{ L Nervus tibialis-AH } \\
\hline Ank1e & AH & Ank1e-AH & NR & NR & NR & NR & & & NR \\
\hline
\end{tabular}

F Wave(Advanced)

\begin{tabular}{|l|l|l|l|l|l|l|l|l|l|l|l|}
\hline Nerve & $\begin{array}{l}\text { Min F } \\
\text { Lat } \\
\mathrm{ms}\end{array}$ & $\begin{array}{l}\text { Max } \\
\mathrm{F} \\
\text { Lat } \\
\mathrm{ms}\end{array}$ & $\begin{array}{l}\text { Mean } \\
\text { FLat } \\
\mathrm{ms}\end{array}$ & $\begin{array}{l}\text { \%F } \\
\%\end{array}$ & $\begin{array}{l}\text { Min M } \\
\text { Amp } \\
\mathrm{mV}\end{array}$ & $\begin{array}{l}\text { Max M } \\
\text { Amp } \\
\mathrm{mV}\end{array}$ & $\begin{array}{l}\text { Mean } \\
\text { MAmp } \\
\mathrm{mv}\end{array}$ & $\begin{array}{l}\text { M-CV } \\
\mathrm{m} / \mathrm{s}\end{array}$ & $\begin{array}{l}\text { Min } \\
\mathrm{F} \\
\text { Amp } \\
\mathrm{mV}\end{array}$ & $\begin{array}{l}\text { Max } \\
\mathrm{F} \\
\text { Amp } \\
\mathrm{mV}\end{array}$ & $\begin{array}{l}\text { Mean } \\
\text { FAmp } \\
\mathrm{mV}\end{array}$ \\
\hline $\begin{array}{l}\text { R Nervus } \\
\text { tibialis -AH }\end{array}$ & & & 0 & 0.54 & 0.57 & 0.55 & 30.2 & & & \\
\hline $\begin{array}{l}\text { R Median } \\
\text { nerve -ADM }\end{array}$ & 37.8 & 39.4 & 38.6 & 20 & 0.57 & 0.65 & 0.61 & 32.4 & 0.07 & 0.12 & 0.10 \\
\hline $\begin{array}{l}\text { R UInar } \\
\text { nerve -ADM }\end{array}$ & 29.3 & 39.6 & 35.7 & 80 & 3.80 & 3.62 & 3.70 & 47.2 & 0.06 & 0.19 & 0.13 \\
\hline $\begin{array}{l}\text { L Median } \\
\text { nerve -ADM }\end{array}$ & 25.5 & 35.0 & 30.7 & 50 & 1.36 & 1.69 & 1.56 & 39.2 & 0.03 & 0.13 & 0.10 \\
\hline $\begin{array}{l}\text { L Ulnar } \\
\text { nerve -ADM }\end{array}$ & 30.6 & 33.2 & 31.6 & 90.9 & 5.40 & 5.54 & 5.47 & 51.1 & 0.06 & 1.14 & 0.43 \\
\hline
\end{tabular}

\begin{tabular}{|c|c|c|c|c|c|}
\hline \multicolumn{6}{|c|}{ EMG Summary Table } \\
\hline \multirow[b]{2}{*}{ Muscle } & \multicolumn{3}{|l|}{ rest } & \multicolumn{2}{|l|}{ contraction } \\
\hline & $\begin{array}{l}\text { fibrillation/ } \\
\text { positive sharp } \\
\text { wave }\end{array}$ & $\begin{array}{l}\text { fasciculation } \\
\text { potential }\end{array}$ & \begin{tabular}{|l|}
$\begin{array}{l}\text { Special } \\
\text { potential }\end{array}$ \\
\end{tabular} & phase & amplitude $\mathrm{mV}$ \\
\hline $\begin{array}{l}\text { R. tibialis } \\
\text { anterior }\end{array}$ & $2+$ & NO & NO & Pure phase & 5.0 \\
\hline $\begin{array}{l}\text { L. Medial } \\
\text { head of } \\
\text { quadriceps } \\
\text { femoris }\end{array}$ & $2+$ & NO & NO & mixed phase & 4.5 \\
\hline $\begin{array}{l}\text { R. First Dorsal } \\
\text { Interosseous }\end{array}$ & $1+$ & NO & NO & mixed phase & 4.5 \\
\hline $\begin{array}{l}\text { L. } \\
\text { genioglossus }\end{array}$ & NO & NO & NO & $\begin{array}{l}\text { Interference } \\
\text { phase }\end{array}$ & 2.0 \\
\hline $\begin{array}{l}\text { R. straight } \\
\text { muscle of } \\
\text { abdomen }\end{array}$ & NO & NO & NO & & \\
\hline
\end{tabular}

Multi MUP
\begin{tabular}{|l|l|l|l|}
\hline Muscle & Amplitude $\mu \mathrm{V}$ & $\begin{array}{l}\text { Dur. } \\
\mathrm{ms}\end{array}$ & Phases \\
\hline R tibialis anterior & 1332.8 & 15.8 & 3.1 \\
\hline $\begin{array}{l}\text { L Medial head of } \\
\text { quadriceps femoris }\end{array}$ & 3303.8 & 16.46 & 3.7 \\
\hline $\begin{array}{l}\text { R First Dorsal } \\
\text { Interosseous }\end{array}$ & 2325.2 & 12.36 & 3.5 \\
\hline L genioglossus & $\underline{724.4}$ & $\underline{8.53}$ & $\underline{3.1}$ \\
\hline
\end{tabular}

Figure 1: Electroneuromyography. 
weak and swelling of both lower limbs had increased, so the hormone was stopped; Repeated questioning of medical history with different family members, the patient's family members reminded that the patient's sister had numbness in the distal right upper limb in the past few months; the patient had a son who also had right finger numbness in the past month, and the symptoms appeared intermittently (none of which was examined and treated); Combining the patient's symptoms, signs, and related auxiliary examinations, family history, and perfecting the full genetic examination, it was found that the patient had a mutation in the TTR gene, and the patient's son and sister also had mutations in the gene locus (2). The final diagnosis: familial hereditary amyloidosis and peripheral neuropathy (FAP).

\section{Discussion}

The pathogenesis of FAP is due to Transthyretin (TTR) gene mutation, TTR gene is located in the long arm of chromosome 18 ,Val30Mel is the most common form of mutation, abnormal folding of the Transthyretin protein to form amyloid substances that can be deposited in peripheral nerves and heart tissues [1,2]. FAP is divided into early-onset and late-onset FAP, early-onset tend to have disease at the age of 20 to 40 , early involvement without pulp fiber or thin on the far side of pulp fibers cause pain temperature significantly affected, such as numbness, tenderness, hyperesthesia, spontaneous pain, and is not sensitive to heat and cold, autonomic nerve symptoms and early, such as digestive tract symptoms, Orthostatic hypotension, etc. Later stages involve myelinated fibers, including mild tactile, positional and vibratory involvement, and length-dependent impairment of lower limb motor functions, such as difficulty walking and muscle weakness. Patients with late onset tend to develop the disease at more than 50 years old, usually with sensorimotor symptoms at the distal end of the lower limbs as the first manifestation, and both deep and shallow sensation are moderately involved. Early walking difficulties may occur. About $10 \%$ of patients present with mild autonomic symptoms, such as digestive tract symptoms, orthostatic hypotension, and sexual dysfunction. Often accompanied by hypertrophy of the heart, the performance of syncope, shortness of breath and other symptoms [3].

A heterozygous mutation in the TTR gene (c349G>T pAla117Ser) was detected in this family, HGMD database ID CM003484, and the mutation grade is DM (pathogenic mutation) (Figure 2); Liu YT., et al. reported that the TTR gene P. Ala97Ser (same as P. Ala117Ser) mutation was detected in 5 cases of hereditary amy- loidosis, presenting with late onset polyneuropathy, carpal tunnel syndrome and obvious autonomic nerve dysfunction [4]. Yang CC., et al. reported that skin biopsy of 19 patients with inherited amyloidosis carrying the TTR gene P Ala97Ser mutation showed a significant decrease in the density of epidermal nerve fibers, and dermal denervation occurred in all patients [5]. The onset of the patients after 40 years of age, without apparent autonomic nerve dysfunction, in addition to the peripheral nerve damage has no obvious other organ damage. His son and sister also gradually started to peripheral nerve damage, but the future family will appear the autonomic nerve function damage and other organ involvement should be further follow-up.

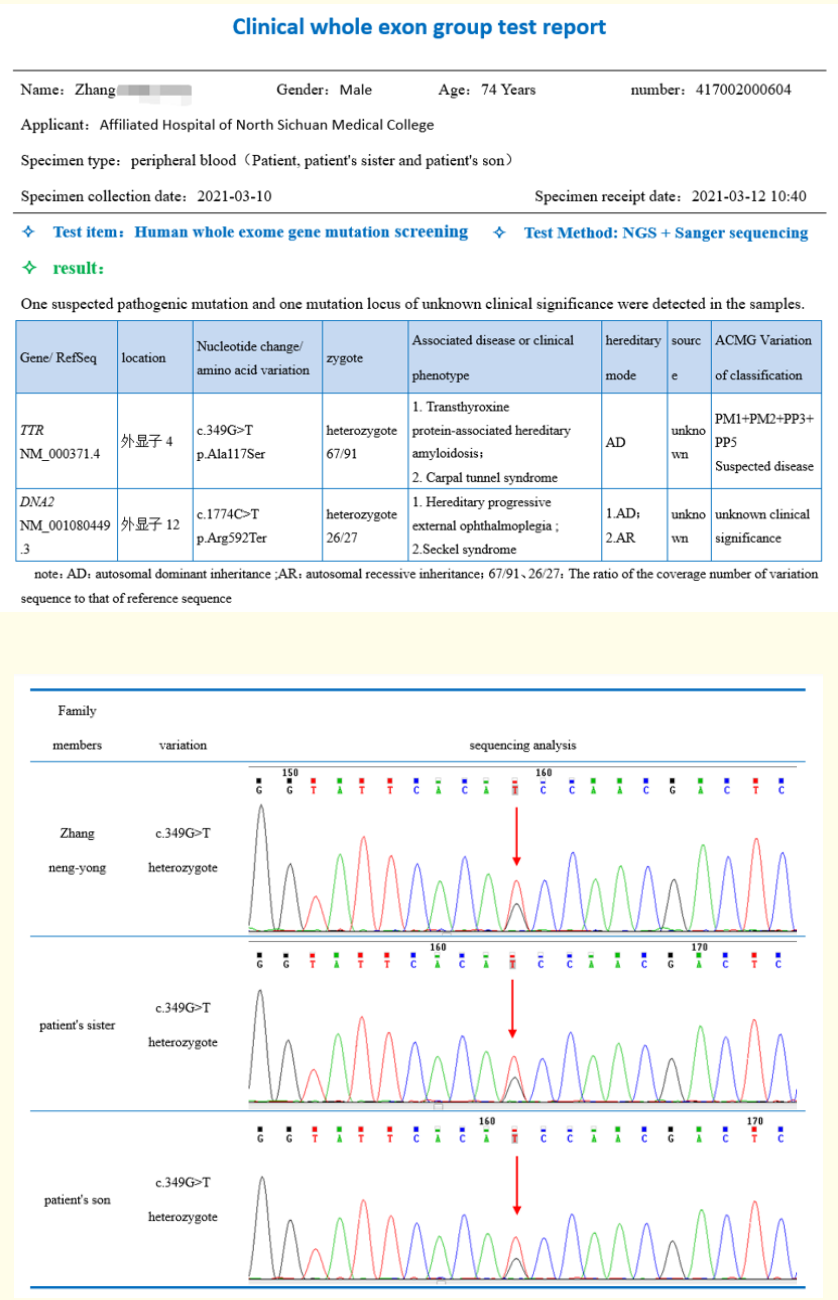

Figure 2: Sanger sequencing peak map of TTR gene c.349G>T site. 


\section{Conclusion}

This patients, slow onset, duration long, disease progression, progressive numbness of limbs weakness as the main performance, suspected with autonomic nervous function damage (double leg below the knee mild skin edema, thinning of the nails and matt), and no obvious other organ (such as eye, heart, kidney, etc.) damage except peripheral nerve damage, especially the patient denied any family history. Nerve conduction and electromyography showed multiple peripheral nerve damage, cerebrospinal fluid examination to rule out chronic Gillan barre syndrome, make diagnosis in trouble. Patients with history of repeatedly cross-examine eventually found suspicious family history, perfecting the genetic testing and found that patients with TTR event gene mutations, His sister and son also carried the same mutation, so he was eventually diagnosed with FAP. Therefore, in clinical work, in addition to other common diseases, FAP should also be considered for patients with only peripheral nerve damage and a family history.

\section{Bibliography}

1. V Planté-Bordeneuve and Said G. "Familial amyloid polyneuropathy”. The Lancet Neurology 10.12 (2011): 1086-1097.

2. Adams D., et al. "European consensus for diagnosis, management, and treatment of transthyretinfamilial amyloid polyneuropathy". Current Opinion in Neurology 29.1 (2016): S14-26.

3. Sekijima Y., et al. "Diagnosis and management of transthyretin familial amyloid polyneuropathy in Japan: red-flag symptom clusters and treatment algorithm". Orphanet Journal of Rare Diseases 13.1 (2018): 6.

4. Liu YT., et al. "Transthyretin Ala97Ser in Chinese-Taiwanese patients with familial amyloid polyneuropathy: Genetic studies and phenotype expression". Journal of the Neurological Sciences 267.1-2 (2008): 91-99.

5. Yang CC., et al. "Clinical presentations and skin denervation in amyloid neuropathy due to transthyretin Ala97Ser". Neurology 75.6 (2010): 532-538.

Volume 4 Issue 12 December 2021

(C) All rights are reserved by Zhang Xiao-Dong., et al. 